DOI: $10.19195 / 0137-1134.109 .18$

KATARZYNA ŁUCARZ

Uniwersytet Wrocławski

\title{
ZMIANA ZAKRESU ZAKAZU PROWADZENIA POJAZDÓW MECHANICZNYCH W POSTĘPOWANIU WYKONAWCZYM
}

Zapewne chcąc złagodzić krańcowość obecnej regulacji prawnej zakazu prowadzenia pojazdów, ustawą z dnia 20 marca 2015 r. ${ }^{1}$ wprowadzono do rodzimego porządku prawnego nieznane dotąd rozwiązanie, na podstawie którego sąd może orzec o dalszym wykonywaniu tego środka karnego w postaci zakazu prowadzenia pojazdów niewyposażonych w blokadę alkoholową, jeżeli był on wykonywany przez okres co najmniej połowy orzeczonego wymiaru, a w wypadku dożywotniego zakazu prowadzenia pojazdów przez okres co najmniej 10 lat oraz jeżeli postawa, właściwości i warunki osobiste sprawcy, tudzież jego zachowanie w okresie wykonywania, uzasadniają przekonanie, że prowadzenie pojazdu przez tę osobę nie zagraża już dłużej bezpieczeństwu w komunikacji (art. 182a § 1 k.k.w.).

Nie potrzeba chyba dalej dodawać, że w związku z takim, a nie innym ustawowym ujęciem tego przepisu zrodziła się od razu podstawowa wątpliwość co do charakteru prawnego instytucji w nim zawartej. Wbrew intuicji językowej nie jest to bowiem nowa postać zakazu prowadzenia pojazdów. Decydujący w tej mierze art. 39 pkt 3 k.k. stanowi przecież wprost o „zakazie prowadzenia pojazdów”. Fakt, że ustawodawca rozwija tę ogólną nazwę w kolejnym przepisie art. 42 k.k., określającym przesłanki aplikacji tego środka karnego, oznacza tylko tyle, że sąd zmuszony jest każdorazowo określić zakres przedmiotowy tego środka karnego, pozostając w zgodzie ze wskazaniami wynikającymi z poszczególnych podstaw prawnych jego orzeczenia ${ }^{2}$. $Z$ tego też względu uściślenie przez sąd $w$ toku orzekania uprawnień, których dotyczy zakaz, wbrew pozorom nie jest wcale związane $\mathrm{z}$ postacią tego środka karnego, ile z rodzajem pojazdów objętych jego zakresem przedmiotowym.

${ }^{1}$ Ustawa z dnia 20 marca 2015 r. o zmianie ustawy - Kodeks karny oraz niektórych innych ustaw, Dz.U. 2015 poz. 541, dalej: nowela.

2 Konkretyzacja uprawnień odbywa się w ramach formuły „pojazdy określonego rodzaju” (art. 42 § 1 i 2 k.k.), ,,wszelkie pojazdy” (art. 42 § 2 k.k.) albo też „,wszelkie pojazdy mechaniczne” (art. $42 \S 3$ i 4 k.k.). 
Nie jest to też nowy sposób wykonania zakazu prowadzenia pojazdów, chociaż z treści art. 182a $\S 1$ k.k.w. mogłoby wynikać zupełnie co innego, wszak mowa tam wyraźnie o dalszym wykonywaniu zakazu prowadzeniu pojazdów. A już stanowczo należy odrzucić twierdzenie, iż mamy tutaj do czynienia z nowym jakościowo środkiem karnym ${ }^{3}$. Nie wydaje się, aby w tej sytuacji dochodziło do zasadniczego zakwestionowania decyzji sądu rozstrzygającej w postępowaniu jurysdykcyjnym, które miałoby rzekomo polegać na odstąpieniu od istoty zakazu stanowiącego treść środka pierwotnie orzeczonego ${ }^{4}$. Takie stanowisko polega na pewnym nieporozumieniu. Przede wszystkim nie można tracić z pola widzenia, że sens instytucji przewidzianej w art. 182a $\S 1$ k.k.w. sprowadza się do umożliwienia skazanemu wcześniejszego, niżby to wynikało z orzeczenia sądowego powrotu do udziału w ruchu drogowym w charakterze prowadzącego pojazd. Sąd na podstawie przepisu art. 182a § 1 k.k.w. w postępowaniu wykonawczym ogranicza jedynie prawomocnie orzeczony zakaz prowadzenia pojazdów do uprawnień dotyczących prowadzenia pojazdów niewyposażonych w blokadę alkoholową. Zmienia zatem tylko zakres przedmiotowy zakazu zasądzonego w postępowaniu rozpoznawczym. W rezultacie tego zamiast o nowym środku karnym należałoby mówić raczej o twórczym rozwinięciu rozwiązań prawnych dotyczących tego właśnie środka karnego, które mają odwrócić, przynajmniej częściowo, negatywne skutki wynikające z podwyższenia ustawowych granic wymiaru zakazu prowadzenia pojazdów. To oznacza, że zastosowany na podstawie art. 182a $\S 1$ k.k.w. zakaz prowadzenia pojazdów mechanicznych niewyposażonych w blokadę alkoholową nie ma bytu samoistnego, przeciwnie - ściśle powiązany z pierwotnym zakazem stanowi nieco zmodyfikowaną wersję tego ostatniego. Dodajmy, że dość atrakcyjną z punktu widzenia samego skazanego, który w braku takiej alternatywy byłby zmuszony odbyć zakaz w całości w zakresie uprzednio ustalonym w wyroku sądowym. W dodatku oceny tej nie przekreśla bynajmniej konieczność zainstalowania blokady alkoholowej.

Rozstrzygniecie charakteru prawnego art. 182a $§ 1$ k.k.w., choć niewątpliwie ważne i pożyteczne, nie oczyszcza jeszcze se ipse instytucji w nim uregulowanej ze wszystkich wątpliwości czy też niejasności, jakich może ona dostarczyć w przyszłości praktyce wymiaru sprawiedliwości. Nie do końca szczęśliwy sposób sformułowania tego przepisu generuje bowiem kolejne pytanie o to, czy przewidziana w nim możliwość odnosi się do każdego zakazu, niezależnie od podstawy prawnej jego orzeczenia, czy też tylko tego zastosowanego na podstawie art. $42 \S 2$ k.k. lub art. $42 \S 3$, ewentualnie $\S 4$ k.k. Ponieważ art. 182a § 1 k.k.w. wymienia wyraźnie w swej treści przepisy stanowiące podstawę orzeczenia za-

${ }_{3}^{3}$ R.A. Stefański, Zakaz prowadzenia pojazdów, [w:] Środki karne po nowelizacji w 2015 roku, red. R.A. Stefański, Warszawa 2016, s. 279-288; idem, Skrócenie okresu zakazu prowadzenia pojazdów, [w:] Meandry prawa karnego i kryminalistyki. Księga jubileuszowa prof. zw. dra hab. Stanisława Pikulskiego, red. J. Kasprzak, W. Cieślak, I. Nowicka, Szczytno 2015, s. 235-236, 246-248.

4 Pismo Prokuratora Generalnego z 17 grudnia 2014 r., nr PG VII G 025/206/14 (niepubl.), s. 3. 
kazów dożywotnich, przeto kwestia objęcia ich zakresem działania tej normy nie powinna podlegać żadnej dyskusji. Podobnie rzecz przedstawia się z terminowym zakazem określonym w art. $42 \S 2$ k.k. — a to dlatego, że alternatywa w postaci ograniczenia zakazu do pojazdów niewyposażonych w blokadę alkoholową wchodzi w rachubę wyłącznie wtedy, gdy ten był wykonywany przez okres co najmniej połowy orzeczonego wymiaru. Warto również zauważyć, że w stosunku do skazanych na ten rodzaj zakazu przepis art. 182a $\S 1$ k.k.w. stanowi tak naprawdę jedyny dopuszczalny sposób wcześniejszego prowadzenia pojazdów objętych jego zakresem ze względu na wyraźne wyłączenie w art. 84 § 2 k.k. możliwości przedterminowego uznania go za wykonany.

$\mathrm{Z}$ tego dalej wynika, że założona $\mathrm{w}$ art. $182 \mathrm{a} \S 1$ k.k.w. redukcja zakresu przedmiotowego zakazu do pojazdów niewyposażonych w blokadę alkoholową powinna dotyczyć wyłącznie tych skazanych, wobec których orzeczono ten środek karny z powodu popełnienia przestępstwa przeciwko bezpieczeństwu w komunikacji w stanie nietrzeźwości (art. 42 § 2, 3 i 4 k.k.) — wszak to głównie oni powodują zagrożenie dla bezpieczeństwa $\mathrm{w}$ ruchu, któremu ma przeciwdziałać montaż alkoblokady. Problem pojawia się natomiast wówczas, gdy dochodzimy do zakazu orzekanego na podstawie art. $42 \S 1$ k.k. Literalne brzmienie art. 182a $\S 1$ k.k.w. nie sprzeciwia się bowiem stosowaniu możliwości w nim unormowanej także względem zakazu z art. $42 \S 1$ k.k.w., skoro mowa tam o orzeczonym zakazie prowadzenia pojazdów, bez dookreślenia, że chodzi jedynie o ten orzeczony na podstawie art. $42 \S 2$ k.k.w. ${ }^{5}$ To jednak, co z językowego punktu widzenia można by jeszcze uznać za uzasadnione, okazuje się zupełnie chybione ze względów celowościowych. Przede wszystkim, jak już wspomniano, przepis ten, zgodnie z zamysłem ustawodawcy, ma ograniczać ryzyko udziału w ruchu skazanych lekceważących zasadę bezwzględnej trzeźwości. Chodzi przecież o to, by nie prowadzili oni pojazdu w stanie intoksykacji alkoholowej — taki jest praktyczny cel korzystania z blokady alkoholowej. O tym zaś, że nie mogą tego uczynić, świadczy fakt, iż blokada alkoholowa uniemożliwia uruchomienie pojazdu, jeśli zawartość alkoholu w wydychanym przez kierującego powietrzu wynosi co najmniej $0,1 \mathrm{mg}$ alkoholu w $1 \mathrm{dm}^{3}$ (art. 2 pkt 84 p.r.d. $)^{6}$. $\mathrm{Z}$ tej też przyczyny akceptacja sta-

5 R.A. Stefański, Zmiana zakresu zakazu prowadzenia pojazdów mechanicznych w postępowaniu wykonawczym, PnD 2015, nr 8, s. 39.

6 Wykazuje ona przeto istotne walory zabezpieczające, skoro zapobiega rozruchowi silnika po wykryciu alkoholu w stężeniu, które przekracza wartość identyfikowaną już ze stanem po użyciu alkoholu. Niezależnie od rodzaju urządzenia zwykle przed uruchomieniem pojazdu kierowca musi bowiem podać próbkę wydychanego powietrza i w wypadku, gdy stężenie alkoholu w wydychanym powietrzu jest niższe od ustawionej wartości granicznej, następuje uwolnienie rozrusznika silnika, z kolei gdy stężenie przekracza ową bezpieczną wartość graniczną, dochodzi do blokady silnika, przez co podjęcie jazdy jest niemożliwe. Blokada alkoholowa wykrywa przy tym próby dokonania pomiaru wydychanego powietrza z użyciem specjalnego sprzętu (np. pompki) w miejsce analizatora oddechu. Również wszelkie manipulacje oraz próby obejścia urządzenia i uruchomienia silnika pod wpływem alkoholu są rejestrowane w jej pamięci. 
nowiska, że przepis ten poszerza tak naprawdę sądowi paletę możliwości reakcji, nie wprowadzając przy tym dyferencjacji pomiędzy sprawcami i nie ograniczając możliwości de facto złagodzenia środka tylko do pewnych grup osób skazanych ${ }^{7}$, jest poważnie utrudniona, o ile w ogóle możliwa. Również dlatego, że w wypadku sprawców skazanych na zakaz z art. 42 § 1 k.k. przekształcenie go po upływie wymaganego kwantum w zakaz prowadzenia pojazdów niewyposażonych w blokadę alkoholową będzie oznaczać co najwyżej szybszy ich powrót za kierownicę. Dla przykładu, jeśli sąd zastosuje zakaz prowadzenia pojazdów mechanicznych na okres 1 roku, wówczas zgodnie z art. 182a $§ 1$ k.k.w. już po upływie sześciu miesięcy (czyli połowy okresu wykonywania zakazu) skazani będą mogli ubiegać się o zmianę tego środka karnego na zakaz prowadzenia pojazdów niewyposażonych w blokadę alkoholową. Jest przy tym oczywiste, iż taka praktyka może wyłącznie podważyć walor wychowawczy regulacji w nim przewidzianej. Tymczasem trzeba pamiętać, że tą drogą ustawodawca zamierza pobudzić prowadzących pojazdy do zachowania daleko idącej ostrożności na drodze.

Nieco inaczej ma się sprawa w wypadku skazanych na zakaz z art. 42 § 1 k.k. za przestępstwo komunikacyjne popełnione w stanie po użyciu alkoholu. Tutaj bowiem nie tylko względy językowe, lecz także sam „stan po użyciu alkoholu” przemawia za objęciem ich zakresem art. $182 \mathrm{a} \S 1$ k.k.w. ${ }^{8}$ Pomimo tego, a może raczej na przekór temu, nie wydaje się, aby byli oni w praktyce zainteresowani skorzystaniem z nowo wprowadzonej regulacji. Dalej idące profity daje im przecież art. $84 \S 1$ k.k., który pozwala sądowi po upływie połowy okresu, na jaki orzeczono zakaz, uznać go za wykonany w całości. Pod warunkiem rzecz jasna, że skazany przestrzegał w tym czasie porządku prawnego, a zakaz był wykonywany w stosunku do niego przynajmniej przez rok. W odróżnieniu od art. 182a $\S 1$ k.k.w., który umożliwia warunkowe prowadzenie pojazdu skazanym na zakaz za przestępstwo lub wykroczenie popełnione w stanie intoksykacji alkoholowej, w przepisie art. $84 \S 1$ k.k. chodzi o faktyczne ograniczenie czasu wykonania zakazu prowadzenia pojazdów. Ilekroć bowiem skazany na zakaz prowadzenia pojazdów wykaże się pozytywną postawą, sąd zyskuje za jego sprawą uprawnienie do bezwarunkowego uznania zakazu za wykonany przed upływem okresu wynikającego z orzeczenia zasądzającego ten środek karny. W efekcie skazany nie jest już dłużej krępowany żadnymi ograniczeniami generowanymi przez zakaz prowadzenia pojazdów.

7 Wypowiedź T. Darkowskiego na 82 posiedzeniu Komisji Nadzwyczajnej do spraw zmian w kodyfikacjach w dniu 18 grudnia 2014 r., Biuletyn nr 4118/VII, http://www.sejm.gov.pl/SQL2. nsf/poskomprocall?OpenAgent\&7\&2586 (dostęp: 27.06.2015).

$8 \mathrm{Z}$ uwagi na treść art. $1 \S 1$ k.k.w. rozwiązanie zawarte w art. 182a k.k.w. znajduje też zastosowanie do zakazu prowadzenia pojazdów orzeczonego za wykroczenia popełnione po użyciu alkoholu. Zgodnie z przywołaną regulacją przepisy kodeksu karnego wykonawczego stosuje się bowiem do orzeczeń wydanych w postępowaniu w sprawach o wykroczenia. 
Zastosowanie art. 182 a $§ 1$ k.k.w. uzależnione zostało od spełnienia warunku formalnego związanego z okresem wykonywania zakazu, który musi upłynąć. $\mathrm{W}$ razie terminowego zakazu jest to co najmniej połowa orzeczonego wymiaru. Dla ścisłości dodajmy, że jego wielkość uzależniona jest każdorazowo od rozmiaru okresu, na jaki orzeczono ten środek karny. To dlatego, że stanowi on pochodną wymiaru zakazu określonego w wyroku. Bez znaczenia natomiast dla jego obliczenia pozostaje bieg zakazu prowadzenia pojazdów. Wprawdzie może się zdarzyć, że okres zakazu wskazany w wyroku pokryje się z jego biegiem, ale nie zawsze musi tak być.

Biorąc pod uwagę, że obligatoryjny zakaz prowadzenia pojazdów orzekany jest na minimalny okres 3 lat (art. $42 \S 2$ k.k. w zw. z art. $43 \S 1$ k.k.), należałoby przyjąć, zgodnie z regułami matematycznymi, iż modyfikacja zakresu przedmiotowego dopuszczalna jest najwcześniejszej po upływie roku i 6 miesięcy. Z uwagi na treść art. $43 \S 1$ k.k. i wynikającą z niej konieczność orzekania tego zakazu w latach pojawia się jednak pytanie, czy okres wykonania tego środka karnego można ustalać także w miesiącach. Rozstrzygając tę kwestię, nie wolno przeoczyć, że art. $43 \S 1$ k.k. wyznacza wyłącznie granice temporalne, w jakich sąd określa okres trwania zakazu, podczas gdy art. $182 \S 1$ a k.k. traktuje wyraźnie o okresie wykonywania tego środka karnego, a ten należy zawsze określać według reguł matematycznych. Twierdzenie, że kwantum wykonanego zakazu stanowi najbliższy okres mierzony w latach, prowadziłoby zresztą do przyjęcia dwóch granic: roku lub 2 lat, z których każda byłaby trudna do zaakceptowania. Pierwsza bowiem w sposób całkowicie nieuprawniony premiowałaby skazanego, druga z kolei mogłaby jawić się dlań jako zbyt krzywdząca. Chcąc uniknąć tego rodzaju nieprawidłowości, należałoby zatem przyjąć granicę wynikającą z wyliczenia matematycznego, tj. 18 miesięcy. Za takim rozwiązaniem analizowanej kwestii przemawia też art. 6 cytowanej noweli. Wynika z niego, że wobec osób, w stosunku do których przed dniem wejścia noweli w życie orzeczono prawomocnym wyrokiem środek karny zakazu prowadzenia pojazdów na podstawie art. $42 \S 2$ k.k., przepis art. 182a k.k.w. stosuje się, o ile ten środek karny był wykonywany przez co najmniej 18 miesięcy. Skoro więc ustawodawca w okresie przejściowym nakazuje obliczać ten okres w miesiącach, to właściwie nie ma jakichkolwiek przeszkód uniemożliwiających stosowanie tego miernika w każdej innej sytuacji ${ }^{9}$. W rezultacie w razie orzeczenia zakazu na podstawie art. $42 \S 1$ k.k., którego dolna ustawowa granica ukształtowana jest na poziomie roku (art. $43 \S 1$ k.k.), minimalny okres jego wykonania powinien wynosić 6 miesięcy. A w wypadku zakazu orzeczonego za wykroczenie, którego ustawowe minimum kształtuje się na poziomie 6 miesięcy (art. $29 \S 1$ k.k.), niezbędne jest wykonywanie go przez okres co najmniej 3 miesięcy. Natomiast dożywotni zakaz prowadzenia pojazdów trzeba wykonywać, zgodnie z treścią art. 182 a $§ 1$ k.k.w., przez co najmniej 10 lat.

9 R.A. Stefański, Zmiana zakresu..., s. 41-42. 
$\mathrm{Na}$ tym jednak nie koniec. Poza warunkiem formalnym dopuszczalność modyfikacji zakresu przedmiotowego zakazu prowadzenia pojazdów na etapie postępowania wykonawczego domaga się spełnienia jeszcze drugiej przesłanki, choć o nieco odmiennej naturze. Sięgając po omawiane rozwiązanie, sąd musi bowiem powziąć przekonanie, że prowadzenie pojazdu przez daną osobę nie będzie ponownie zagrażało bezpieczeństwu w komunikacji, a formułując tego rodzaju pozytywną prognozę wesprzeć się na takich okolicznościach, jak: postawa, właściwości i warunki osobiste sprawcy, tudzież jego zachowanie się w okresie wykonywania środka karnego. Ponieważ wszystkie one stanowiły już przedmiot dociekań doktryny prawa karnego, dla niniejszych rozważań wystarczające powinno być przypomnienie, iż w zakresie postawy sprawcy decydujące znaczenie ma jego stosunek do powszechnie uznanych wartości społecznych, jak i samego czynu, w następstwie którego orzeczony został zakaz prowadzenia pojazdów. Do właściwości osobistych zalicza się z kolei takie cechy, jak: wiek, płeć, poziom rozwoju intelektualnego, stan zdrowia psychicznego i fizycznego, cechy charakteru, temperament, podatność na wpływy, zdolności, zainteresowania, ambicje, nałogi, stosunek do siebie samego, innych ludzi i otaczającego świata ${ }^{10}$. Natomiast warunki osobiste obejmują: warunki materialne, mieszkalne, zdrowotne, rodzinne i socjalne, które tworzą zespół czynników środowiskowych wyznaczających pozycję społeczną sprawcy przestępstwa, skalę jego potrzeb, głównie bytowych, jak też możliwości ich zaspokojenia ${ }^{11}$. Doceniając wagę i znacznie powyższych okoliczności, łatwo jednak spostrzec, że dla całościowej prognozy kryminologicznej skazanego najważniejszym jej komponentem pozostawać będzie zachowanie się skazanego w okresie wykonywania zakazu prowadzenia pojazdów. To ostatecznie z nim wiąże się cały ciężar ustalenia, czy powrót skazanego do ruchu w charakterze prowadzącego pojazd ponownie doprowadzi do zagrożenia dla jego bezpieczeństwa. Dobrym prognostykiem w tym zakresie przykładowo może okazać się niekaralność za przestępstwo lub wykroczenie przeciwko bezpieczeństwu w ruchu drogowym albo też niekaralność za przestępstwo z art. 244 k.k. Z reguły bowiem stwierdzenie takiej karalności dowodzi braku dyscypliny społecznej i przez to negatywnie wpływa na ocenę osoby skazanej.

O tym, że tak jest, przekonuje dodatkowo regulacja art. 84 § 2a k.k., która zakłada możliwość uznania całego środka orzeczonego dożywotniego za wykonany. Dzieje się to wtedy, gdy zakaz wykonywany był przez okres przynajmniej 15 lat, sam skazany zaś przestrzegał porządku prawnego i nie zachodzi obawa powtórnego popełnienia przestępstwa podobnego do tego, za które już raz prawomocnie orzeczono ten środek karny. Aby ograniczyć możliwe w tym zakresie ryzyko błędu, organ orzekający powinien zatem wpierw wyłączyć z formuły zaka-

10 Z. Sienkiewicz, [w:] O. Górniok et al., Kodeks karny. Komentarz, t. 1, Gdańsk 2005, s. 527.

11 K. Buchała, [w:] K. Buchała, A. Zoll, Kodeks karny. Część ogólna. Komentarz, t. 1, Kraków 1998, s. 397. 
zu uprawnienia do prowadzenia pojazdów z blokadą alkoholową, a następnie, po pozytywnej ocenie zachowania skazanego w tym okresie, uznać go za wykonany w całości ${ }^{12}$. Jest to jednak praktyczne zalecenie — ani Kodeks karny, ani też Kodeks karny wykonawczy nie zawierają bowiem takiej dyrektywy ${ }^{13}$.

Przekształcony na podstawie art. $182 \mathrm{a} \S 1 \mathrm{k} . \mathrm{k} . \mathrm{w}$. zakaz prowadzenia pojazdów pod względem przedmiotowym obejmuje uprawnienia do prowadzenia pojazdów niewyposażonych w blokadę alkoholową. W efekcie osoba, wobec której zastosowano taki sposób modyfikacji orzeczonego zakazu, zyskuje uprawnienie do prowadzenia pojazdów wyposażonych w taką blokadę ${ }^{14}$. Natomiast w pozostałym zakresie nadal obowiązuje pierwotnie orzeczony zakaz.

Z definicji blokady wynika, że jest to urządzenie techniczne uniemożliwiające uruchomienie silnika pojazdu silnikowego oraz pojazdu szynowego. Z tego względu wyłączenie z zakresu zakazu prowadzenia pojazdów może dotyczyć uprawnień do prowadzenia tylko tych pojazdów, chociaż na podstawie art. 42 $\S 1$ oraz 2 k.k. możliwe jest orzeczenie zakazu prowadzenia również innego rodzaju pojazdów. Pomimo tego norma art. 182a $\S 1$ k.k.w. jest na tyle pojemna, że pozwala objać zakresem swego działania uprawnienia do prowadzenia niemal wszystkich pojazdów wyposażonych w silnik (pojazd silnikowy oraz szynowy) z wyjątkiem motoroweru (art. 2 pkt 23 p.r.d.). Ma przeto wystarczająco szerokie spektrum zastosowania.

Przepisy Kodeksu karnego wykonawczego nie określają co prawda wprost, przez jaki okres ma być wykonywany zakaz prowadzenia pojazdów niewyposażonych w blokadę alkoholową. Niemniej jednak już na podstawie samego

12 R.A. Stefański, Zakaz prowadzenia..., s. 284.

13 R.A. Stefański, Zmiana zakresu..., s. 43.

14 Osoba, względem której zmodyfikowano zakaz w sposób określony w art. 182a § 1 k.k.w. może prowadzić pojazd wyposażony w blokadę alkoholową tylko, jeśli posiada uprawnienia do kierowania nim, stwierdzone prawem jazdy odpowiedniej kategorii. Dlatego starosta, w myśl art. 103 ust. 3a ustawy z dnia 5 stycznia 2011 r. o kierujących pojazdami (Dz.U. 2015 poz. 155 ze zm.), przywraca uprawnienia takiej osobie, a wydając decyzję o przywróceniu uprawnień do kierowania pojazdami, dokonuje z urzędu wpisu do prawa jazdy, zawierającego informację o ograniczeniu uprawnienia do kierowania wyłącznie pojazdem wyposażonym w blokadę alkoholową przez okres trwania orzeczonego zakazu. I dopiero po uiszczeniu właściwych opłat wydaje prawo jazdy takiej kategorii, którą sprawca uprzednio posiadał. Warunkiem koniecznym przywrócenia uprawnień jest jednak złożenie przez skazanego, z wynikiem pozytywnym, odpowiedniego do rodzaju uprawnienia egzaminu państwowego sprawdzającego kwalifikacje (art. 49 ust. 2 ustawy o kierujących pojazdami). Sprawdzeniu kwalifikacji w tej właśnie formie podlega bowiem osoba, która ubiega się o przywrócenie, m.in. uprawnienia do kierowania pojazdami silnikowymi, cofniętego na okres przekraczający 1 rok (art. 49 ust. 1 pkt 3 lit. a ustawy o kierujących pojazdami). Osoba taka przed przywróceniem uprawnień podlega też badaniu lekarskiemu, które przeprowadza się w celu ustalenia istnienia lub braku przeciwskazań zdrowotnych do kierowania pojazdami (art. 75 ust. 1 pkt 4, art. 75 ust. 2 pkt 2 ustawy o kierujących pojazdami). Spełnienie przez skazanego obu wspomnianych warunków stanowi do pewnego stopnia gwarancję, że posiada on zarówno kwalifikacje, jak i stan zdrowia, które umożliwiają mu bezpieczne uczestniczenie w ruchu w charakterze kierującego pojazdem. 
sformułowania „sąd może orzec o dalszym wykonywaniu tego środka karnego w postaci zakazu prowadzenia pojazdów niewyposażonych w blokadę alkoholową" wywieść można, że trwa on nieprzerwanie do upływu okresu, na który został pierwotnie orzeczony zakaz prowadzenia pojazdów. W wypadku zakazu terminowego granica ta jest łatwa do uchwycenia, albowiem wynika z wyroku sądowego. Przy jej obliczaniu należy jedynie uwzględnić zawieszenie jego biegu. W sytuacji dożywotniego zakazu konsekwentnie trzeba przyjąć, że jest on bezterminowo wykonywany w zmienionym zakresie przedmiotowym (ewentualnie do czasu zastosowania dobrodziejstwa wynikającego z art. 84 § 2a k.k.).

Dokonanie modyfikacji zakazu prowadzenia pojazdów na mocy art. 182a $\S 1$ k.k.w. nie musi jednak wcale oznaczać konieczności wykonywania go w takiej formule przedmiotowej do końca okresu wynikającego z orzeczenia sądowego. Sąd bowiem, w myśl art. 182 a $\S 3$ k.k.w., może orzec o uchyleniu sposobu wykonywania zakazu prowadzenia pojazdów w postaci zakazu prowadzenia pojazdów niewyposażonych w blokadę alkoholową, jeżeli skazany rażąco naruszył porządek prawny w zakresie dotyczącym bezpieczeństwa drogowego, w szczególności zaś popełnił przestępstwo przeciwko bezpieczeństwu w komunikacji. $\mathrm{Z}$ treści tego przepisu wynika więc, że nie każde naruszenie porządku prawnego w zakresie zasad dotyczących bezpieczeństwa ruchu drogowego prowadzi do uchylenia zmodyfikowanego zakazu, a tylko takie, które znamionuje się jaskrawym czy też oczywistym wystąpieniem przeciwko nim i z którym z tego właśnie powodu wiąże się wytworzenie stanu znacznego zagrożenia dla bezpieczeństwa w tym ruchu. Podkreślić przy tym należy, że owo naruszenie porządku prawnego odniesione zostało tylko do bezpieczeństwa ruchu drogowego ${ }^{15}$, co eliminuje z zakresu działania tego przepisu zarówno naruszenia drogowe o charakterze czysto porządkowym, jak i wszystkie te, które mają miejsce w sferze ruchu wodnego oraz powietrznego.

$\mathrm{W}$ charakterze pewnej podpowiedzi ustawodawca dodaje jeszcze, że przykładem naruszenia, które może skutkować odwołaniem zakazu prowadzenia pojazdów niewyposażonych w blokadę alkoholową, jest popełnienie przestępstwa przeciwko bezpieczeństwu w komunikacji ${ }^{16}$. Doceniając jej znaczenie, bez trudu wszak można zauważyć, iż nie zachował on tutaj pożądanej korelacji. Zgodnie z przeważającym stanowiskiem doktryny zwrot „komunikacja” poza sferą ruchu drogowego obejmuje również sferę ruchu kolejowego, wodnego oraz powietrz-

15 Może więc ono wchodzić w rachubę w razie popełnienia niektórych wykroczeń przeciwko bezpieczeństwu w komunikacji (np. z art. 87 § 1 k.w., art. 87 § 1a k.w., art. $87 \S 2$ k.w., art. $86 \S 1$ k.w.).

16 Należy zastrzec, że prowadzenie pojazdu bez blokady alkoholowej nie stanowi podstawy prowadzącej do uchylenia zmodyfikowanego na mocy art. 182a $\S 1$ k.k.w. zakazu. To dlatego, że zachowanie takie wyczerpuje znamiona przestępstwa z art. 244 k.k., które nie jest skierowane przeciwko bezpieczeństwu w komunikacji. Przedmiotem ochrony tego przepisu jest prawidłowe funkcjonowanie wymiaru sprawiedliwości, którego niezbędnym warunkiem jest zapewnienie wykonania określonych orzeczeń sądowych. Brak respektowania wynikających z nich zakazów lub zobowiązań podważa bowiem autorytet sądu. 
nego. Pod względem semantycznym wykracza zatem znacznie poza ten rodzaj ruchu, z myślą o którym ustawodawca projektował akurat instytucję przewidzianą w art. 182a k.k.w. Skoro zaś tak, należałoby postulować zastąpienie obecnie obowiązującego $\mathrm{w}$ tej materii sformułowania bardziej adekwatnym, bo ściślej powiązanym z ruchem drogowym, jak choćby - „przestępstwa przeciwko bezpieczeństwu w ruchu drogowym, czy nieco szerzej w ruchu lądowym”. Takie zawężające ujęcie wynika nie tylko z alokacji rozwiązań dotyczących blokady alkoholowej w przepisach o ruchu drogowym. Równie istotne są też konsekwencje uchylenia się skazanego od zakazu prowadzenia pojazdów niewyposażonych w blokadę alkoholową. Wypełnienie powyższej przesłanki skutkuje przecież powrotem do „punktu wyjścia”. W rezultacie skazany musi odbyć w całości orzeczony pierwotnie zakaz prowadzenia pojazdów mechanicznych. Co może okazać się szczególnie dotkliwe w sytuacji, gdy zdążył się on już przyzwyczaić do legalnego prowadzenia pojazdu, choć wyposażonego w blokadę alkoholową.

Pomijając w tym miejscu widoczną niekonsekwencję terminologiczną ustawodawcy, trzeba zaznaczyć, że również popełnienie przestępstwa tego rodzaju nie musi w każdym wypadku wiązać się z zastosowaniem rygorów przewidzianych w art. 182a $\S 3$ k.k.w. Wszak przepis ten mówi jedynie o możliwości, a nie obowiązku. To dowodzi, że tego rodzaju decyzję zawsze powinna poprzedzać kompleksowa ocena zdarzenia, która najogólniej rzecz ujmując, sprowadza się do porównania postępowania należytego i możliwego w danych warunkach z rzeczywistym zachowaniem się sprawcy. Im większa między nimi różnica, tym większe prawdopodobieństwo uchylenia zmodyfikowanego zakazu i powrót do jego wcześniejszej wersji ${ }^{17}$.

Decyzja $\mathrm{w}$ tym zakresie wydawana jest rzecz jasna w formie postanowienia, na które skazanemu przysługuje zażalenie (art. 182a $§ 4$ k.k.w.). Warto dodać, że nie jest to jedyny możliwy sposób weryfikacji tego rodzaju rozstrzygnięcia procesowego. Zakotwiczenie zmiany zakresu przedmiotowego zakazu prowadzenia pojazdów w przepisach karno-wykonawczych otwiera bowiem skazanemu niezadowolonemu z decyzji sądu drogę do skorzystania w każdym właściwie czasie z nieco dalej idącej regulacji art. $24 \S 1$ k.k.w. ${ }^{18}$ Przepis ten dopuszcza zmianę lub uchylenie orzeczeń w postępowaniu wykonawczym, ilekroć w sprawie pojawiają się nowe lub nieznane dotąd okoliczności faktyczne o istotnym wszakże znaczeniu dla zapadłego rozstrzygnięcia. Co ważniejsze jednak, możliwość korygowania

${ }^{17}$ Uchylenie zakazu prowadzenia pojazdów niewyposażonych w blokadę alkoholową z powodu popełnienia przestępstwa komunikacyjnego może nastąpić tylko wówczas, gdy to ostatnie zostanie potwierdzone prawomocnym wyrokiem sądowym. Wynika to z zasady domniemania niewinności, w myśl której oskarżonego uważa się za niewinnego, dopóki jego wina nie zostanie stwierdzona prawomocnym wyrokiem (art. 42 ust. 3 Konstytucji RP oraz art. 5 k.p.k.).

18 Kontrola dokonywana w trybie art. 24 k.k.w. dotyczy w równym stopniu zarówno postanowień prawomocnych, jak i tych, dla których po ich wydaniu nadal biegnie termin do wniesienia zażalenia. 
orzeczeń w trybie art. $24 \S 1$ k.k.w. pozostaje praktycznie niczym nieograniczona. W konsekwencji nie da się wykluczyć wielokrotnego nawet stosowania tego przepisu do postanowień, które już uprzednio na tej właśnie podstawie uchylono bądź zmieniono. Oczywiście w każdym wypadku warunkiem takiej korekty jest, aby zmieniająca się sytuacja faktycznie wpływała na ocenę wcześniej wydanego postanowienia w sposób w nim opisany. Nie kwestionując w żadnym razie potrzeby funkcjonowania na odcinku wykonawczym tego rodzaju „wentyla bezpieczeństwa", trudno jednocześnie bagatelizować fakt, że stworzona przezeń sposobność do „piętrowego" wręcz modyfikowania decyzji sądu o uchyleniu zakazu prowadzenia pojazdów niewyposażonych $\mathrm{w}$ blokadę alkoholową może prowadzić prostą drogą do wypaczenia istoty instytucji zawartej w art. 182a $§ 1$ k.k.w. A przypomnijmy, że ma ona pełnić rolę swoistej „nagrody” dla tych skazanych, którzy dobrze rokują na przyszłość. Nie bez powodu przecież art. 182a § 3 k.k.w. wymaga przede wszystkim przestrzegania zasad bezpieczeństwa $\mathrm{w}$ ruchu drogowym. Jest więc zrozumiałe, że w takiej perspektywie szczególnego znaczenia nabiera wprowadzenie do art. 182a k.k.w. nowego zapisu, na podstawie którego możliwość korzystania z tego instrumentu procesowego $\mathrm{w}$ analizowanych sprawach byłaby wyraźnie limitowana pod względem czasowym. Takie rozwiązanie pozwoliłoby niewątpliwie zapobiec wszelkiego rodzaju nadużyciom w tym zakresie.

Na koniec wreszcie warto zauważyć, że pomieszczona w art. 182a $§ 1$ k.k.w. instytucja ogranicza się wyłącznie do skazanych na zakaz prowadzenia pojazdów za przestępstwo popełnione w związku ze stanem nietrzeźwości lub stanem pod wpływem alkoholu. Pomija natomiast zupełnie i bez reszty skazanych na analogiczny zakaz z tą jednak różnicą, że za przestępstwo popełnione pod wpływem środka odurzającego lub w związku z ucieczką z miejsca zdarzenia ${ }^{19}$. A przecież, jak wspomniano, są oni pozbawieni ex lege możliwości skorzystania z instytucji przedterminowego uznania zakazu za wykonany w całości (art. $84 \S 2$ k.k.). Taki stan rzeczy prowadzi niewątpliwie do nierównego traktowania skazanych za przestępstwa, w wypadku których jedynym ich wyróżnikiem jest albo rodzaj wprowadzonej do organizmu substancji psychoaktywnej, albo też zbiegnięcie z miejsca zdarzenia. Nierówność tę dodatkowo wzmacnia fakt, że skazany za przestępstwo popełnione w stanie nietrzeźwości, który zbiegł z miejsca zdarzenia, może skorzystać z omawianej modyfikacji zakazu, gdy tymczasem ten, który tylko zbiegł, jest jej pozbawiony ${ }^{20}$. I chociaż zarzut ten jest poważny, to jednak przyznać trzeba, że do pewnego stopnia usprawiedliwiony, przynajmniej w odniesieniu do skazanych, wobec których orzeczono zakaz za przestępstwo komunikacyjne popełnione pod

19 Ta uwaga odnosi się również do znamienia „, pod wpływem podobnie działającego środka”, które właściwe jest prawu wykroczeń.

20 R.A. Stefański, Zakaz prowadzenia..., s. 281-282; D. Mieczkowska, Walka z nietrzeźwościa w ruchu komunikacyjnym droga nowelizacji prawa karnego. Uwagi na temat zmian w regulacji zakazu prowadzenia pojazdów, PnD 2015, nr 9, s. 17. 
wpływem środka odurzającego, brakiem urządzeń technicznych analogicznych do blokad alkoholowych. Stąd też nie wydaje się, aby mógł on stanowić wystarczający argument przemawiający przeciwko wprowadzeniu czy dalszemu utrzymaniu tego rodzaju regulacji. Wprost przeciwnie, należałoby ją powitać z niemałym entuzjazmem, zresztą tak jak wszelkie próby poszukiwania instrumentów prawnokarnych, które redukując nadmierną surowość zakazu prowadzenia pojazdów, zmierzają jednocześnie do zapewnienia skutecznej ochrony bezpieczeństwa w komunikacji.

\section{CHANGING THE SCOPE OF THE BAN ON DRIVING MOTOR VEHICLES IN ENFORCEMENT PROCEEDINGS}

\section{Summary}

The presented study treats about the possibility of changing the scope of ban at the executory proceedings stage, introduced by the Act of 20 March 2015, of amending the Penal Code and some other acts. The authoress introduces details of this regulation, pointing out certain inaccuracies which are featured by her. 